\title{
FIELD APPLICATION OF ENTOMOPATHOGENIC NEMATODES AGAINST ZEUZERA PYRINA (L.) AND PAROPTA PARADOXA (H. SCHAEFF) IN EGYPT
}

\author{
Ahmed Mohammed Azazy \\ Plant Protection Research Institute
}

\begin{abstract}
Field application of entomopathogenic nematodes (Heterorhabditis taysariiy (Ht), Heterorhabditis $\mathrm{sp}$ (TWF), Heterorhabditis bacteriophora (HP88) and Steinernema carpocapsae (Sc)) against fruit tree borers were performed in 2008 seasons in different governorate. Results showed that the method of use of nematodes soaked cotton plugs gave the best results, followed by the injection method and spray method against Zeuzera pyrina on apple trees. When, controlling Paropta paradoxa the injection method was better than the spraying method of the entomopathogenic nematodes on pear trees. Added the starch polymer to nematode suspension increased the infectivity of the three tested nematode species in both methods of (spray and injection) against Z. pyrina. Results showed that the addition of polymerized starch for the three nematodes tested gave high significant increase amounted $81.01 \%$, while using the nematode alone gave $65.4 \%$.
\end{abstract}

Key words: Control, entomopathogenic nematodes, Zeuzera pyrina (L.) and Paropta paradoxa

\section{INTRODUCTION}

Entomopathogenic nematodes of the genera Steinernema and Heterorhabditis have been used to control a wide range of agriculturally important insect pest (Kaya and Gaugler, 1993). Third stage infective juveniles (IJs) of entomopathogenic nematodes detect their potential hosts by physical and chemicals cues including $\mathrm{CO}^{2}$ (Gaugler et al., 1980) and fecal constituents (Schmidt and ALL, 1979) and Azazy (2001). IJs penetrate the host via natural openings such as the mouth, anus and spiracles and release their symbiotic bacteria. The bacteria produce toxins kill the insect hosts within 24-48 hours of penetration (Akhurst and Boemare, 1982). The entomopathogenic nematodes develop by feeding on the symbiotic bacteria and degraded the host tissues, mate and reproduce up to three generations inside their host. The subsequent IJs develop within 7 to 10 and 12 to 14 days Steinernema spp and Heterorhabditis spp, respectively, in response to the nutrients quality of the host cadaver, emerge and search for a new insect host. The insect borers are economically important pests of the fruit trees; apple, olive and pear in Egypt. Such borers have been successfully controlled under field conditions using entomopathogenic nematodes (Clear water and Wouts, 1980; Deseo et al., 1984; Deseo and Miller, 1985; Abdel-Kawy et al., 1992; Abdel-Kawy and El-Bishery, 1992; Azazy, 1996 \& 2001). Several investigators used solutions with various antidesiccants (glycerin, starch and gel) when applying entomopathogenic nematodes to control insects, without

Fayoum J. Agric. Res. \& Dev., Vol.25, No.2, July, 2011 
affecting to the nematodes (Welch and Briand, 1961; Moore 1970; Georges and Hague, 1991.

\section{MATERIALS AND METHODS}

Four of entomopathogenic nematode species were applied against two pests in the field, the leopard moth, Zeuzera pyrina (L.) and the solitary carpenter worm, Paropta paradoxa. The tested nematode species were Heterorhabditis taysariiy (Ht), Heterorhabditis sp (TWF), Heterorhabditis bacteriophora (HP88) and Steinernema carpocapsae (Sc). Two of aforementioned species are native ones isolated form Egypt belong to the genus Heterorhabditis while Heterorhabditis bacteriophora (HP88) and $S$ carpocapsae $(\mathrm{Sc})$ were originally obtained from Biosys, Palto Alto, California).

\section{Methods of application:}

1- The spray technique: Water suspension of different nematodes were prepared and sprayed on the infested apple and pear trees; a portable $1.5 \mathrm{~L}$ sprayer was used. Spray was directed towards infestation regions in the main trunk and branches.

2- The injection technique: The active galleries producing fresh insect frass were injected with the entomopathogenic nematodes suspensions using a $50 \mathrm{cc}$ syringe. Each gallery received approximately $2 \mathrm{ml}$ of nematode suspension.

3- The cotton plug technique: Small balls of cotton were soaked in the nematodes suspensions of the tested species and fixed on the opening of the active galleries.

- In the present study, four experiments were carried out at different Governorates in 2008.

\section{Field trials:}

1- Comparsion between injection and cotton plugs techniques in controlling $Z$. pyrina:-

This study was carried out in EL-Marwa farm at Cairo-Alexandria desert road in 56 apple trees infested with Z. pyrina; four nematode species (Ht, TWF, HP88 and Sc) were used. The concentration of all entomopathogenic nematode species was 2000IJs / $\mathrm{ml}$ distilled water.

2- Comparison between injection and spraying techniques in controlling $Z$. pyrina: The experiment was performed at EL-Gharbia Governorate in 30 apple trees infested with $Z$. pyrina apple trees; three nematode species were tested, Ht, ISK and HP88.

3-Controlling of Paropta paradoxa:-

This study was conducted in 30 pear trees infested with paropta paradoxa at Aboxa Village, EL-Fayoum Governorate, three entomopathogenic nematode species were tested, Ht ISK and HP88.

4-Efficacy of entomopathogenic nematodes combined with starch polymer against Z. pyrina:-

This study was carried out at EL-Noubaria regions in a Zeuzera infested apple orchard. Three nematode species (HP88, TWF and Ht) were used at $1000 \mathrm{IJs} / \mathrm{ml}$. The applied techniques were the spraying and injection. The starch polymer was added to nematode suspension with the rate of $1 \mathrm{gm} /$ liter. Every treatment consisted of 15 trees according to severity of

Fayoum J. Agric. Res. \& Dev., Vol.25, No.2, July, 2011 
FIELD APPLICATION OF ENTOMOPATHOGENIC NEMATODES.. 98

Zeuzera infestation. Control treatments were performed without adding starch. In each trial, treated infested trees were inspected weekly after treatment galleries that had new exploded frass were considered active (i.e., the inside larvae were considered alive).Also, some randomly galleries in the trunk and main branches were inspected by using a sharp knife and a steel string (about $50 \mathrm{~cm}$. long) to look for alive or dead larvae.

Statistical Analysis

The data presented in percentage values in the present study were normalized using arcsine transformation. The significance of the main effects was determined by analysis of variance (ANOVA). The significance of various treatments was evaluated by Duncan's multiple range test $(P<0.05)$. (1955) All analyses were made using a software package "Costat", a product of Cohort Software Inc., Berkeley, California.

\section{RESULTS AND DISCUSSION}

1-Comparsion between the injection and cotton plugs in controlling Z. pyrina:-

The obtained data are shown in table, (1) which indicate that the method of nematode soaked cotton plugs caused higher significant mortality rates $(\mathrm{df}=3 \mathrm{~F}=24.4 \mathrm{P}=.0006)$ for $Z$. pyrina than the injection method. All the entomopathogenic nematode species caused high mortality on Z. pyrina. The bioassay effect was high significant differences between them $(\mathrm{df}=3 \mathrm{~F}=7.7$ $\mathrm{P}=0.0003$ ). Also it is clear that the strain $S$. carpocapsae $(\mathrm{Sc})$ and $\mathrm{Ht}$ caused higher mortality rates than the other two species especially in cotton plug technique $(97.9 \pm 4.5 \%$ and $94.4 \pm 6$ respectively), Ted and Shapiro (2006) reported that Sc strain achieved a higher mortality than S. riborvae on Synanthedon exitiosa in the field and laboratory applications. All interaction effects among the different treatment were high significant ( $\mathrm{df}=3 \mathrm{~F}=6.8$ $\mathrm{P}=0.0007$ ). It must be mentioned that the strain $\mathrm{Ht}$ is native strain. Our results are in agreement with those of Abdel-Kawy et al., (1988 and 1992) who reported that the control of $Z$. pyrina by cotton plug was better than injection method. Azazy, 2001 obtained similar results in controlling $Z$. pyrina and $S$. myopaeformis.

2-Comparison between spraying and injection techniques:

Data in Table (2) show injection method was effective than spraying in controlling $Z$. pyrina. Statistical analysis showed no significant differences among the two methods $(\mathrm{df}=1 \mathrm{~F}=3.5 \mathrm{P}=0.0749)$ and between all tested entomopathogenic nematode species. These results are in coincidence with those of Deseo et al., (1984), Deseo and Docci (1985), Deseo and Miller (1985), Kaya and Brown (1986), Abdel-Kawy et al., (1992) and Saleh et al., (1994).

3-Controlling Paropta paradoxa on pear trees:

Data presented in Table (3) show the efficacy of three entomopathogenic nematodes in controlling $P$. paradoxa. The native strain $(\mathrm{Ht})$ gave better mortality than HP88 and TWF (67.1, 63.5 and 58.9\%, respectively), but not significant differences were found between the nematode species $(\mathrm{df}=2 \mathrm{~F}=0.3$ $\mathrm{P}=0.7714$ ). On the other hand, no significant difference was also found between injection and spray methods $(\mathrm{df}=1 \mathrm{~F}=3.6 \mathrm{P}=0.689)$. These results are in coincidence with those of Deseo et al., (1984), Deseo and Docci (1985), Deseo and Miller (1985), Kaya and Brown (1986) and Abdel-Kawy et al., (1988).

Fayoum J. Agric. Res. \& Dev., Vol.25, No.2, July, 2011 
Fayoum J. Agric. Res. \& Dev., Vol.25, No.2, July, 2011 
FIELD APPLICATION OF ENTOMOPATHOGENIC NEMATODES.. 100

Fayoum J. Agric. Res. \& Dev., Vol.25, No.2, July, 2011 
4- Effect of starch polymer on the efficacy of entomopathogenic nematode species against $Z$. pyrina:

From Table (4), it could be concluded that adding of starch polymer in spraying method gave a higher mortality than spraying the entomopathogenic nematode species alone. However, in the injection method there were no significant differences in mortality percentages among treatments with the entomopathogenic nematode either alone or in combination with the starch polymer. Statistical analysis showed high significant differences were found among nematode species $(\mathrm{df}=3 \mathrm{~F}=9.4 \mathrm{P}=0.0004)$ and two methods ( $\mathrm{df}=1$ $\mathrm{F}=24.5 \mathrm{P}=0.0000$ ). All interaction effects between the treatments were any significant except in the case the nematodes and starch polymer. The nematode strain $\mathrm{Ht}$ was more effective than the two nematode species TWF and HP88 resulted mortalities 79.1, 76.9 and $63.7 \%$, respectively. Using the entomopathogenic nematode with starch polymer or alone gave mortalities of Z. pyrina 80.01 and $65.4 \%$, respectively. This increase of nematodes infectivity could be attributed to that the starch polymer retarded the evaporation of water in the nematode suspension longer times causing the ability of infective juvenile stages (IJs) to search inside the insect larvae galleries, since the environmental condition are suitable for them. These results are in agreement with those of Abdel-Kawy (1985). Schroeder (1990) said that increasing mortality of wax moth, Galleria mellonella (L.), larvae exposed to soil from the starch polymer/nematode treated area occurred compared with water/nematode treatment alone. Generally, tree-boring lepidopterous insects, in particular $Z$. pyrina and $P$. paradoxa live in moist galleries, have been controlled effectively with entomopathogenic nematodes. The moist galleries are ideal for the survival and searching of the nematode. If the galleries opening is too small or the gallery is not sufficient moist, the nematode spray is not effective. It was found that inserting of cotton pieces soaked in nematode suspension into insect gallery gave the better larval mortality followed by injection method. While the spray method of nematode suspensions induced the lowest percent mortality. Generally, the tested entomopathogenic nematode species (HP88, TWF and $\mathrm{Ht}$ ) were more effective against $Z$. pyrina (inducing 85.1, 72.9 and $73.1 \%$ mortality, respectively) than $P$. paradoxa $(63.5,58.9$ and $67.1 \%$, respectively also).

\section{REFERENCES}

Abdel-Kawy, A.M. (1985). Biological control of some lepidopterous pests by the nematode Neoaplectana carpocapsae and the physiological changes associated with it. Ph. D. Thesis, Fac. Agric. Cairo Univ.

Abdel-Kawy, A.M., El-Kifl, T.A.H.; El-Sherif, M.A. and Abdel-Bary, N.A. (1988). Controlling the leopard moth Zeuzera pyrina by the nematode Neoaplectana carpocapsae under field conditions. Bull. Zool. Soc. Egypt, 36:10-119.

Abdel-Kawy, A.M. and El-Bishry, M.H. (1992). Entomopathogenic nematodes as effective agents against some borer insect of orchards. Egypt. J. Appl. Sci., 7(12):180-186.

Abdel-Kawy, A.M.; El-Bishry, M.H. and El-Kifl-T.A.H. (1992). Controlling the leopard moth borer, Zeuzera pyrina by three entomopathogenic nematode species in the field. Bull. Fac. Agric., Univ. Cairo, 43 (2): 769-780.

Fayoum J. Agric. Res. \& Dev., Vol.25, No.2, July, 2011 
FIELD APPLICATION OF ENTOMOPATHOGENIC NEMATODES.. 102

Akhurst, R.J., Boemare N.E. (1988). A numerical taxonomic study of the genus Xenorhabdus (Enterobactericease) and proposed elevation of the subspecies of X.nematophilus to species. J. Gen. Micro.134:1835-1845.

Azazy, A.M. (1996). Biological control of insects with insect parasitic nematodes. Msc. Thesis, Fac. Moshtohor Zagazig Univ. Benha Branch, $82 \mathrm{pp}$.

Azazy, A.M. (2001). Comparative studies between insect pathogenic nematodes and other methods in controlling some soil insects and fruit tree borers. Ph.D. Thesis, Fac. Moshtohor Zagazig Unvi. Benha Branch, 126pp.

Clearwater, J.R., Wouts, W.M. (1980). Preliminary trials on the control of lemon tree borer with nematodes. Proceedings of the 33rd New Zealand weed and pest control conference 133-135.

Deseo, K.V.; Govoni, I. and Miller, L. A. (1984). Use of entomopathogenic nematodes (Rhabditida: Steinernematidae) against different species of Synanthedon (Lepidoptera: Aegeriidae) in apple and persimmon orchards. Difesa-delle -Piante. 7: 5/6,315-330.

Deseo, K.V. and Docci, R. (1985). Microbiological control against Zeuzera pyrina. (Lepidoptera: Cossidae). Difesa-delle-Piante, 8(2): 285- 291, 10 ref., in Atti del Convegno' La Lotta Biologica', Torino, 16 febbraio.

Deseo, K.V. and Miller, L.A. (1985). Efficacy of entomogenous nematodes, Steinernema spp., against clearing moth, Synanthedon spp., in north Italian apple orchard. Nematologica. 1985, 31: 1, 100-108.

Duncan, D.B. (1955). Multiple range and multiple F-tests. Biometrics, 11: 145.

Gaugler, R., Le Beck, L., Nakagaki, B. and Boush, G.M. (1980). Orientation of entomopathogenic nematode Neoaplectana carpocapsae to carbon dioxide. Environ. Entomol.9, 649-652.

Georgis, R. \& Hague, N.G.M. (1991). Nematodes as biological insecticides. Pesticide Outlook 2, 29-32.

Kaya, H.K.; and Brown, L.R. (1986). Field application of entomogenous nematodes for biological control of clearing moth borers in alder and sycamore trees. J. Arboriculture. 1986, 12: 6, 150-154. .

Kaya, H.K.; and Gaugler, R. (1993). Entomopathogenic nematodes. Annual Review of Entomology.38:181-206.

Moore, G.E. (1970). Dendroctonus frontalis infection by DD-136 strain of Neoaplectana carpocapsae and its bacterium complex. Journal of Nematology.2,341-344.

Saleh, M.M.; Semeada, A.M. and EL-Shazly, E.A. (1994). Virulence of native and foreign entomopathogenic nematodes to the apple borer Zeuzera pyrina. Egypt. J. Biol. pest control, 4 (2): 107-112.

Schmidt, J. \& All, J. N. (1979). Attraction of Neoaplectana carpocapsae (Nematoda: Steinernematidae) to common excretory products of insects. Environ. Entomol. 8, p. 55-61.

Schroeder, W.J. (1990). Water-Absorbent Starch Polymer: Survival Aid to Nematodes for Control of Diaprepes abbreviatus (Coleoptera: Curculionidae) in Citrus. The Florida Entomologist Vol. 73, No. 1 (Mar., 1990), pp. 129-132.

Ted, E. Cottrell and David I. Shapiro-Ilan. (2006). Susceptibility of the peach tree borer, Synanthedon exitiosa, to Steinernema carpocapsae and Steinernema riobrave in laboratory and field trials. J. Invert. Path. 92, 85-88.

Fayoum J. Agric. Res. \& Dev., Vol.25, No.2, July, 2011 
Welch, H. E. \& Briand, L.J. (1961). Test of the nematode DD-136 and an associated bacterium for the control of the Colorado potato beetle, Leptinotarsa decemlineata (Say). Canadian Entomologist 93, 759-763.

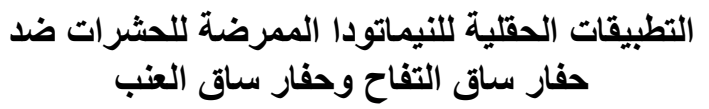

أحمد محمد عزازى إعبة

معهد بحوث وقاية النباتات ـ مركز البحوث الزعاعية ـ وزارة الزراعة ـ مصر

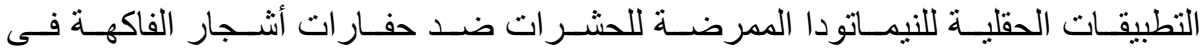

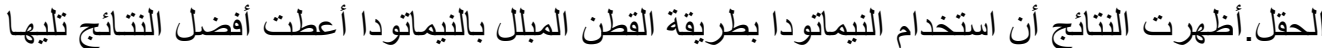

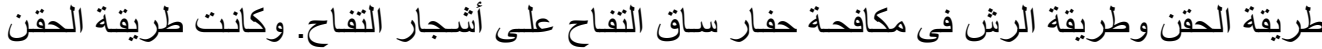

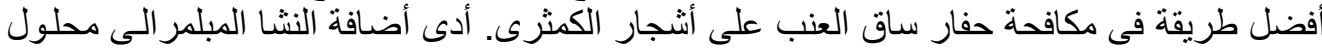

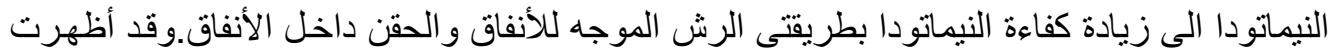

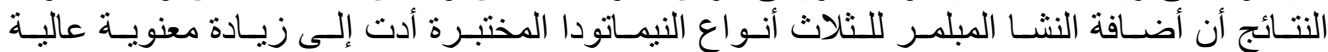

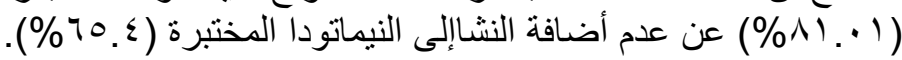

